\title{
ANALYSIS ON THE CYBER VICTIMIZATION AND AWARENESS OF CLASSIFICATION BASKETBALL REFEREES IN TURKEY ${ }^{1}$
}

\section{TÜRKIYY'DE BASKETBOL KLASMAN HAKEMLERININ SIBBER MAĞDURIYETLERI VE FARKINDALIKLARININ INCELENMESİ}

\author{
Serdar ORHAN ${ }^{1}$, Engin AKARSU ${ }^{2}$, A. Serdar YÜCEL ${ }^{3}$, Yüksel SAVUCU ${ }^{4}$ \\ ${ }^{1-3-4}$ University of Firat, Faculty of Sports Sciences, Elazig / Turkey \\ ${ }^{2}$ Austrian Basket Fighters Club Basketball Coaches Vienna / Austria
}

ORCID ID: 0000-0002-7988-5045, 0000-0003-3346-2466, 0000-0002-4543-4123, 0000-0002-2749-6806

Öz: Amaç: Bu çalıșma, Türkiye'de basketbol klasman hakemlerinin siber mağduriyet ve farkındalığını arastırmak amacıyla yapılmıştır. Yöntem: Türkiye'de basketbol klasman hakemlerinin siber mağduriyetleri ve farkındalıklarının incelenmesi amacıyla yapılan bu çalışmaya; Türkiye Basketbol Liglerinde A, B ve C Klasmanlarında görev yapan toplam 206 basketbol hakemi katıldı. Basketbol hakemlerine; Arıcak ve ark. tarafindan geliștirilen 14 maddelik Siber Duyarlılık Ölceği ile aynı kișiler tarafindan geliștirilen 24 maddelik Siber Mağduriyet Ölçeği uygulandı. Elde edilen veriler istatistik paket programında değerlendirildi, ikili karşılaștırmalarda parametrik testlerden T Testi, coklu karsılasstırmalarda Anova kullanıldı. Bulgular: Araştırma sonucunda; basketbol hakemlerinin siber zorbalığa karşı yüksek düzeyde duyarlılık ( = 36.29) gösterdikleri, erkek hakemlerin daha duyarlı oldukları, B klasman hakemlerinin diğer klasman hakemlerinden daha az duyarlılık sergiledikleri istatistiksel olarak anlamlı bulunurken; yas, medeni durum, eğitim durumu, meslek, hakemlik tecrübesi, internette ilk girilen web adresi, günlük internet kullanım süresi, internete ulaşım mekanları ve internete ulaşım araçlarının siber zorbalığa karşı duyarlılığı etkilemediği tespit edildi. Diğer taraftan basketbol hakemlerinin yüksek düzeyde siber mağduriyet $(=43.55$ ) yaşadıkları, B klasman hakemlerinin diğer klasman hakemlerinden daha çok siber saldırıya uğradıkları ve günlük 9-12 saat internet kullananların daha az siber saldırılara maruz kalmaları istatistiksel olarak anlam1. bulunurken; cinsiyet, yaş, medeni durum, eğitim durumu, meslek, hakemlik tecrübesi, internette ilk girilen web adresi, internete ulașım mekanları ve internete ulașım araçlarının siber mağduriyete karşı duyarlılığı etkilemediği tespit edildi. Sonuç: Sonuç olarak, basketbol hakemlerinin siber zorbalığa duyarlılık göstermelerine rağmen siber mağduriyete maruz kaldıkları, ancak günlük internet kullanım süresinin mağduriyet ile ilişkili olmadığı söylenebilir.

Anahtar Kelimeler: Basketbol, Hakem, Siber Mağduriyet, Zorbalık, Siber Duyarlılık
Abstract: Objective: This study was carried out to investigate the cyber victimization and awareness of basketball referees in classification in Turkey. Methods: A total of 206 basketbal referees working as A, B and C classification referees in Turkey Basketball Leagues participated in the study. Basketball referees were applied 14-item Cyber Sensibility Scale and 24-item Cyber Victimization Scale developed by Aricak et al. Data obtained were analyzed with statistical package program. T-parametric tests and Anova test of variance analysis were performed for comparison. Results: In the results of the research, while basketball referees displayed more sensitivity against cyber bullying $(=36.29)$, male referees exhibited more sensitivity than females. B-classification referees have significantly less sensitivity than the referees of other classifications. It has been determined that age, marital status, education, occupation, refereeing experience, priorities on the internet, duration of daily internet use, place of access for the internet and the internet tools don't have any effect on cyber bullying. In other words, basketball referees had a high level of cyber victimization $(=43.55)$; however, B-classification referees were attacked than other classification referees and it was found significantly in term of daily 9-12 hours on the internet usage. Gender, age, marital status, education, occupation, refereeing experience, priorities on the internet, place of access for the internet and the internet tools were found to have no effect on cyber victimization. Conclusion: As a result, the basketball referees are exposed to cyber victimization despite the exhibition of sensitivity and it can be said that there is no relation between victimization and duration of daily internet use.

Key Words: Basketball, Referee, Cyber Victimization, Bullying, Cyber Awareness

Doi: $10.17363 /$ SSTB.2017.3.3

(1) Corresponding Author: Serdar ORHAN, 2Austrian Basket Fighters Club Basketball Coaches Vienna / Austria, sorhan23@gmail.com, Received: 13.06.2017, Accepted: 27.09.2017, Type ofarticle (Research-Application) Conflict of Interest: None / "None of Ethics Committee" 


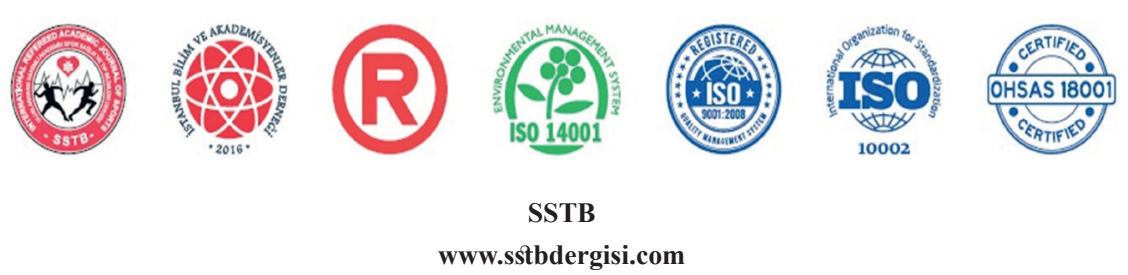

International Refereed Academic Journal of Sports, Health and Medical Sciences

July - August - September Issue 24 Summer Season Year: 2017

JEL CODE: L85-L86 ID:350 K:129

ISSN Print: 2146-8508 Online 2147-1711

(ISO 18001-OH-0090-13001706 / ISO 14001-EM-0090-13001706 / ISO 9001-QM-0090-13001706 / ISO 10002-CM-0090-13001706)

(TRADEMARK)

(2015/04315- 2015-GE-18972)

\section{INTRODUCTION}

Violence and aggression is a type of behavior aiming to harm living and non-living beings. It isn't necessarily obligatory for this behavior to be physical. Every behavior that aims to give verbal and psychological harm is defined as aggression (Cited from Tiryaki, 2010: 149: Pulur vd., 2004: 244). Turkish Language Association defines bully as a person who doesn't allow the individuals - being under his thumb - the right of speech and freedom of act by relying on his power and defines bullying as exhibiting such behaviors. ${ }^{1}$

Cyber bullying is the deliberate and regular transmission of messages and pictures by the individual or a group to others, through information and communication technologies, for the purpose of hostility and intimidation (Patchin and Hinduja, 2006: 152; Ybarra and Mitchell, 2004a: 1310; Ybarra and Mitchell, 2004b: 319-336, Willard, 2005: 13). These texts can contain the messages with very serious content (death threats, profanity, insults, etc.). It also includes actions such as unauthorized reading of other people's e-mails or using their personal passwords, sending embarrassing messages, taking embarrassing pictures of the victim and spreading them (Cited by Erdur-Baker and Kavşut, 2007: 3142)

1 http://www.tdk.gov.tr, 25.12.2014
Cyber bullying and traditional bullying differ from each other in many ways. In the former one, while a physical environment is required for the victim to be harassed in traditional bullying, this isn't necessary in cyber bullying (Patchin and Hinduja, 2006: 154). Another important difference between the traditional and the cyber bullying is the confidentiality of the cyber bullying. For this reason, it is more terrifying and effective. Confidentiality allows the assaulter to be as comfortable as s/ he can't be in real life. The assaulter becomes more frightening and harassing and can even assume another character or personality, as there is no fear that this person can get reactions or be traced (Mesch, 2009: 389; Mishna et al.,2009: 1226).

Cyber bullying is a very common problem that can be experienced at any time in life. It has been reported that there is a significant relation between the possibility of being bullied and intensive use of mobile phone or internet (Patchin and Hinduja, 2006: 152, Arıcak vd., 2008: 258, Kowalski and Limber, 2007: 27; Li, 2006; Moessner, 2007: 1-4; Ybarra et al., 2007: 42-50; Wolak et al., 2007: 55).

It has been extensively researched in many of the researches conducted on cyber bullying whether age is an important determinant and different results have been obtained. In some researches, it has been stated that the relation between age and cyber bullying is insignifi- 


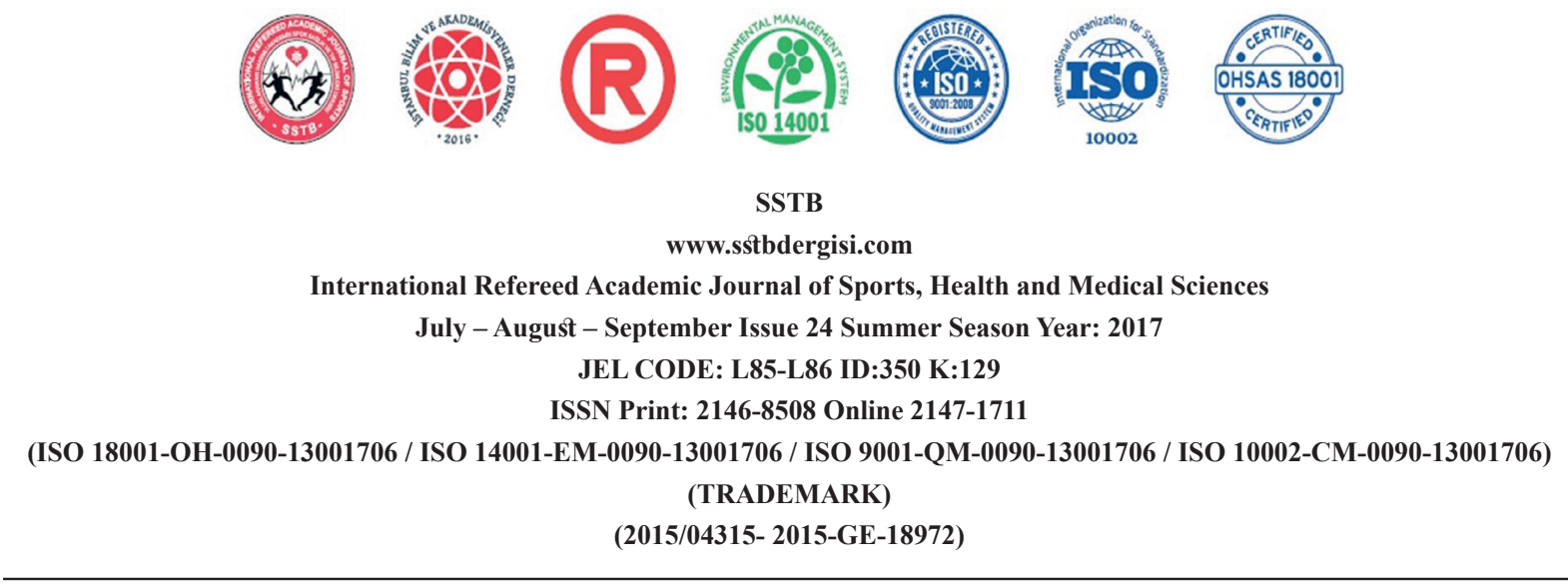

cant (Patchin and Hinduja, 2006: 152; Wolak et al., 2007; Juvonen and Gross, 2008: 499; $\mathrm{Li}, 2007: 1777-1791)$. In the results of the research emphasizing that age is decisive; it is observed that the bullying experience peaks between the ages of 12 and 14 and then declines in next years (Mesch, 2009: 388; Kowalski and Limber, 2007: 22-30; Dehue et al., 2008: 219; Slonje and Smith, 2008: 147-154; Smith et al., 2008: 379; Williams and Guerra, 2007: 17).

The researchers analyzing the gender factor in cyber bullying have obtained different results. Many researchers have pointed out that gender doesn't play a decisive role in cyber bullying and males and females play the roles of victims and bullies at a similar frequency (Patchin and Hinduja, 2006: 160; Slonje and Smith, 2008: 151; Smith et al., 2008: 376385; Williams and Guerra, 2007:17; Topçu vd., 2008: 645). In research results emphasizing that gender difference is decisive, females are observed to be more victimized than males (Mesch, 2009: 389; Arıcak vd., 2008: 257; Kowalski and Limber, 2007: 26; Li, 2007: 1782).

The studies conducted on cyber bullying have shown that cyber bullying negatively affects victims (Cited by Tanrıkulu et al., 2013:42), the feelings of anger, despondency and restlessness are commonly observed in those who are subject to cyber bullying (cited by Horzum and Ayas, 2011: 41), which may lead to many devastating mental health problems that may extend to suicide (Arıcak vd., 2008: 258).

The referees are the individuals assuming responsibility for the management of sports competitions impartially and appropriately for the competition rules. Today, the changes and developments in information technologies attract people from all walks of life into the virtual world and the comments that often cross the boundaries of criticism can turn into cyber harassment and cyber bullying.

Audio or video unreal news, unfounded accusations and defamations, insults based on a certain event, humiliating photomontage and cartoons, criticisms and comments degrading honor and dignity particularly before and after the competition in internet newspapers and on private or commercial websites can directly affect the performance of referees. In this regard, the questions below will be tried to be answered:

1. What are the experiences of basketball referees showing cyber sensitivity and suffering from cyber victimization?

2. Does the cyber sensitivity of basketball referees significantly differ by age, sex, marital status, education, profession, starting year of refereeing, classification, daily use of internet, priorities on internet, place of access for internet and internet tools? 
 \\ www.sstbdergisi.com}

International Refereed Academic Journal of Sports, Health and Medical Sciences

July - August - September Issue 24 Summer Season Year: 2017

JEL CODE: L85-L86 ID:350 K:129

ISSN Print: 2146-8508 Online 2147-1711

(ISO 18001-OH-0090-13001706 / ISO 14001-EM-0090-13001706 / ISO 9001-QM-0090-13001706 / ISO 10002-CM-0090-13001706) (TRADEMARK)

(2015/04315- 2015-GE-18972)

Table 1. Personal Information of Basketball Referees

\begin{tabular}{|c|c|c|c|c|c|}
\hline & $\mathbf{N}$ & $\%$ & & $\mathbf{N}$ & $\%$ \\
\hline Sex & & & Priorities on the Internet & & \\
\hline Male & 178 & 86.4 & Facebook & 63 & 30.6 \\
\hline Female & 28 & 13.6 & Twitter & 17 & 8.3 \\
\hline Age & & & News and newspaper & 24 & 11.7 \\
\hline $20-25$ & 70 & 33.9 & Chat rooms & 20 & 9.7 \\
\hline $26-30$ & 69 & 33.5 & Music & 22 & 10.7 \\
\hline $31-35$ & 37 & 18.0 & Movie, TV series & 13 & 6.3 \\
\hline $36-40$ & 23 & 11.2 & Video websites & 11 & 5.3 \\
\hline $40-45$ & 7 & 3.4 & Video chat & 17 & 8.3 \\
\hline Profession & & & E-mail & 10 & 4.9 \\
\hline Student & 45 & 21.8 & Online Game & 5 & 2.5 \\
\hline Self-employed & 89 & 43.2 & Banking Services & 4 & 1.9 \\
\hline Civil-servant & 71 & 35.0 & Place of Access for Internet & & \\
\hline Education & & & Home & 115 & 55.8 \\
\hline Associate degree & 13 & 6.3 & Internet cafe & 65 & 31.6 \\
\hline Bachelor's degree & 147 & 71.4 & Free places & 21 & 10.2 \\
\hline Master's degree & 39 & 18.9 & Workplace & 5 & 2.4 \\
\hline PhD & 7 & 3.4 & Internet Tools & & \\
\hline Classification & & & Desktop computers & 33 & 16.0 \\
\hline A-classification & 30 & 14.6 & Mobile phones & 57 & 27.7 \\
\hline B-classification & 63 & 30.6 & Tablets & 58 & 28.2 \\
\hline C-classification & 113 & 54.9 & Laptop computers & 33 & 16.1 \\
\hline
\end{tabular}

As specified in Table 2, it is observed that basketball referees display the highest sensitivity in the items of "I never share my passwords related to e-mail and forum registrations etc."
(85.92\%) and "I do not communicate with people who are abusive or insulting in virtual environments" $(81.07 \%)$ in cyber sensibility inventory. 
 \\ www.sstbdergisi.com}

International Refereed Academic Journal of Sports, Health and Medical Sciences

July - August - September Issue 24 Summer Season Year: 2017

JEL CODE: L85-L86 ID:350 K:129

ISSN Print: 2146-8508 Online 2147-1711

(ISO 18001-OH-0090-13001706 / ISO 14001-EM-0090-13001706 / ISO 9001-QM-0090-13001706 / ISO 10002-CM-0090-13001706)

(TRADEMARK)

(2015/04315- 2015-GE-18972)

Table 2. Arithmetic Mean and Percentage Values of the Replies of Referees Given to Cyber Sensibility Inventory

\begin{tabular}{|c|c|c|c|c|c|c|c|c|}
\hline NO & Questions & & No & Sometimes & Yes & $\mathbf{N}$ & $\mathbf{x}$ & S.S. \\
\hline \multirow[t]{2}{*}{1} & \multirow{2}{*}{$\begin{array}{l}\text { I pay attention to keeping an updated virus } \\
\text { program on my computer. }\end{array}$} & $\mathrm{N}$ & 15 & 35 & 156 & \multirow[b]{2}{*}{206} & \multirow[b]{2}{*}{2.68} & \multirow[b]{2}{*}{0.60} \\
\hline & & $\%$ & 7.28 & 16.99 & 75.73 & & & \\
\hline \multirow{2}{*}{2} & \multirow{2}{*}{$\begin{array}{l}\text { I bear in mind that my information can be stolen } \\
\text { by others on the internet. }\end{array}$} & $\mathrm{N}$ & 5 & 41 & 160 & \multirow{2}{*}{206} & \multirow{2}{*}{2.75} & \multirow{2}{*}{0.49} \\
\hline & & $\%$ & 2.43 & 19.90 & 77.67 & & & \\
\hline \multirow{2}{*}{3} & \multirow{2}{*}{$\begin{array}{l}\text { I keep in mind that my private information on } \\
\text { social networking sites (Facebook, Twitter etc.) } \\
\text { can be used maliciously by others. }\end{array}$} & $\mathrm{N}$ & 5 & 61 & 140 & \multirow{2}{*}{206} & \multirow{2}{*}{2.66} & \multirow{2}{*}{0.53} \\
\hline & & $\%$ & 2.43 & 29.61 & 67.96 & & & \\
\hline \multirow{2}{*}{4} & \multirow{2}{*}{$\begin{array}{l}\text { I try not to encounter with the people I have } \\
\text { problems in real life in virtual environment. }\end{array}$} & $\mathrm{N}$ & 13 & 54 & 139 & \multirow{2}{*}{206} & \multirow{2}{*}{2.61} & \multirow{2}{*}{0.60} \\
\hline & & $\%$ & 6.31 & 26.21 & 67.48 & & & \\
\hline \multirow[b]{2}{*}{5} & \multirow{2}{*}{$\begin{array}{l}\text { I feel I need to take some precautions in order } \\
\text { to prevent others from harming me in virtual } \\
\text { environments. }\end{array}$} & $\mathrm{N}$ & 12 & 80 & 114 & \multirow[b]{2}{*}{206} & \multirow[b]{2}{*}{2.50} & \multirow[b]{2}{*}{0.61} \\
\hline & & $\%$ & 5.83 & 38.83 & 55.34 & & & \\
\hline \multirow[b]{2}{*}{6} & \multirow{2}{*}{$\begin{array}{l}\text { I keep in mind that a hacker in a virtual } \\
\text { environment can also pose danger to me. }\end{array}$} & $\mathrm{N}$ & 15 & 54 & 137 & \multirow[b]{2}{*}{206} & \multirow[b]{2}{*}{2.59} & \multirow[b]{2}{*}{0.62} \\
\hline & & $\%$ & 7.28 & 26.21 & 66.50 & & & \\
\hline & I think someone who wants to hurt me can do it & $\mathrm{N}$ & 12 & 65 & 129 & 206 & 257 & 060 \\
\hline 1 & through internet and mobile phones etc. & $\%$ & 5.83 & 31.55 & 62.62 & 206 & 2.31 & 0.60 \\
\hline & I never share my passwords related to e-mail and & $\mathrm{N}$ & 1 & 28 & 177 & & & \\
\hline 8 & forum registrations etc. & $\%$ & 0.49 & 13.59 & 85.92 & 206 & 2.85 & 0.37 \\
\hline 0 & I do not communicate with people who are & $\mathrm{N}$ & 3 & 36 & 167 & 206 & 280 & 044 \\
\hline 9 & abusive or insulting in virtual environments. & $\%$ & 1.46 & 17.48 & 81.07 & 200 & 2.00 & 0.44 \\
\hline 10 & I sometimes imagine the danger that a picture or & $\mathrm{N}$ & 13 & 73 & 120 & & & \\
\hline & $\begin{array}{l}\text { image that I do not want to be seen can spread } \\
\text { unaware of me. }\end{array}$ & $\%$ & 6.31 & 35.44 & 58.25 & 206 & 2.52 & 0.61 \\
\hline & I think that irrelevant rumors may spread about & $\mathrm{N}$ & 27 & 63 & 116 & & & 071 \\
\hline 11 & me on communication in virtual environments. & $\%$ & 13.11 & 30.58 & 56.31 & 206 & 2.43 & 0.71 \\
\hline & I keep in mind that internet can also be used to & $\mathrm{N}$ & 12 & 79 & 115 & & & \\
\hline 12 & harm other people. & $\%$ & 5.83 & 38.35 & 55.83 & 206 & 2.50 & 0.61 \\
\hline & I am sometimes worried about what to do if & $\mathrm{N}$ & 36 & 102 & 68 & & & \\
\hline 13 & $\begin{array}{l}\text { a false information about me spreads on the } \\
\text { internet. }\end{array}$ & $\%$ & 17.48 & 49.51 & 33.01 & 206 & 2.16 & 0.70 \\
\hline & I do not communicate in the virtual environment & $\mathrm{N}$ & 22 & 23 & 161 & & & \\
\hline 14 & $\begin{array}{l}\text { with the people who can threaten me via e-mail } \\
\text { or text message (SMS) from my mobile phone. }\end{array}$ & $\%$ & 10.68 & 11.17 & 78.16 & 206 & 2.67 & 0.66 \\
\hline
\end{tabular}


ISSN Print: 2146-8508 Online 2147-1711

(ISO 18001-OH-0090-13001706 / ISO 14001-EM-0090-13001706 / ISO 9001-QM-0090-13001706 / ISO 10002-CM-0090-13001706) (TRADEMARK)

(2015/04315- 2015-GE-18972)

As specified in Table 3, it is observed that basketball referees experience victimization most in the items of "My friends or other people on the Internet sent me a virus warning message (e-mail)." (74.3\%) and "Unpleasant messages were sent to me on the internet" (52.4\%) in cyber sensibility inventory.

Table 3. Arithmetic Mean and Percentage Values of the Replies of Referees Given to Cyber Victimization Inventory

\begin{tabular}{|c|c|c|c|c|c|c|c|}
\hline NO & Questions & & Yes & No & $\mathbf{N}$ & $\mathbf{X}$ & S.S. \\
\hline \multirow[b]{2}{*}{1} & \multirow{2}{*}{$\begin{array}{l}\text { Someone on the internet has used my name to open } \\
\text { an e-mail account (such as MSN, Yahoo, Gmail, } \\
\text { Mynet). }\end{array}$} & $\mathrm{N}$ & 35 & 171 & \multirow{2}{*}{206} & \multirow{2}{*}{1.85} & \multirow{2}{*}{0.38} \\
\hline & & $\%$ & 17 & 83 & & & \\
\hline \multirow{2}{*}{2} & \multirow{2}{*}{$\begin{array}{l}\text { Someone else secretly used my name to open } \\
\text { accounts on sites like Facebook and Twitter. }\end{array}$} & $\mathrm{N}$ & 46 & 160 & \multirow{2}{*}{206} & \multirow{2}{*}{1.79} & \multirow{2}{*}{0.42} \\
\hline & & $\%$ & 22.3 & 77.7 & & & \\
\hline \multirow{2}{*}{3} & \multirow{2}{*}{$\begin{array}{l}\text { My friends or other people used my personal } \\
\text { information on the Internet. }\end{array}$} & $\mathrm{N}$ & 30 & 176 & \multirow{2}{*}{206} & \multirow{2}{*}{1.85} & \multirow{2}{*}{0.35} \\
\hline & & $\%$ & 14.6 & 85.4 & & & \\
\hline \multirow{2}{*}{4} & \multirow{2}{*}{$\begin{array}{l}\text { My friends or other people sent me a virus warning } \\
\text { message (e-mail) on the Internet. }\end{array}$} & $\mathrm{N}$ & 153 & 53 & \multirow{2}{*}{206} & \multirow{2}{*}{1.26} & \multirow{2}{*}{0.44} \\
\hline & & $\%$ & 74.3 & 25.7 & & & \\
\hline \multirow{2}{*}{5} & \multirow{2}{*}{$\begin{array}{l}\text { My friends or other people used my passwords on } \\
\text { the internet without my knowledge. }\end{array}$} & $\mathrm{N}$ & 24 & 182 & \multirow{2}{*}{206} & \multirow{2}{*}{1.88} & \multirow{2}{*}{0.32} \\
\hline & & $\%$ & 11.7 & 88.3 & & & \\
\hline \multirow[b]{2}{*}{6} & \multirow{2}{*}{$\begin{array}{l}\text { My friends or others tried to secretly enter my e-mail } \\
\text { addresses (such as MSN, Yahoo, Gmail, Mynet) } \\
\text { using my passwords on the internet. }\end{array}$} & $\mathrm{N}$ & 29 & 177 & \multirow[b]{2}{*}{206} & \multirow[b]{2}{*}{1.86} & \multirow[b]{2}{*}{0.35} \\
\hline & & $\%$ & 14.1 & 85.9 & & & \\
\hline \multirow{2}{*}{7} & \multirow{2}{*}{$\begin{array}{l}\text { Some people tried to secretly enter my games on the } \\
\text { internet by using my passwords. }\end{array}$} & $\mathrm{N}$ & 27 & 179 & \multirow{2}{*}{206} & \multirow{2}{*}{1.87} & 034 \\
\hline & & $\%$ & 13.1 & 86.9 & & & 0.04 \\
\hline & & $\mathrm{N}$ & 26 & 180 & & & $022=$ \\
\hline $\mathbf{0}$ & 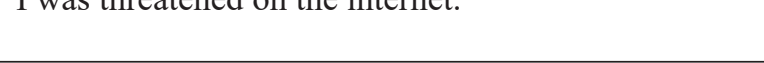 & $\%$ & 12.6 & 87.4 & 200 & 1.81 & 0.35 \\
\hline $\mathbf{0}$ & Unnleacant meccases were sent to me on the internet & $\mathrm{N}$ & 108 & 98 & 206 & 148 & 0.50 \\
\hline 9 & Unpreasant messages were sent to me on the internet. & $\%$ & 52.4 & 47.6 & 200 & 1.40 & 0.50 \\
\hline 10 & My photos were published on some websites without & $\mathrm{N}$ & 40 & 166 & & & \\
\hline & my permission. & $\%$ & 19.4 & 80.6 & 206 & 1.81 & 0.40 \\
\hline 11 & My photos were sent to some people via message & $\mathrm{N}$ & 25 & 181 & 206 & 188 & 033.230 \\
\hline 10 & (e-mail) on the internet without my permission. & $\%$ & 12.1 & 87.9 & 200 & 1.00 & \\
\hline
\end{tabular}




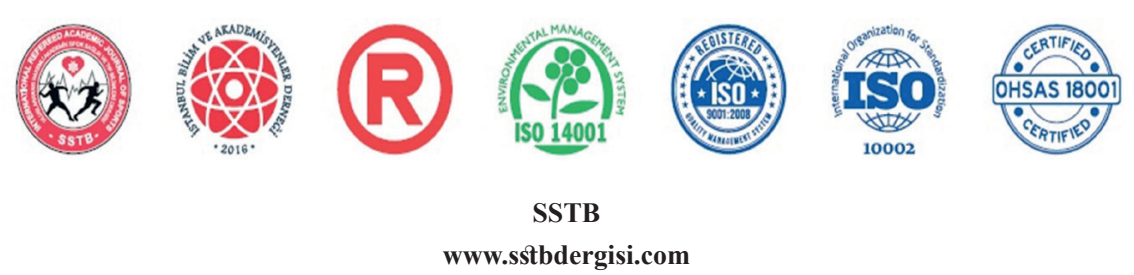

www.sstbdergisi.com

International Refereed Academic Journal of Sports, Health and Medical Sciences

July - August - September Issue 24 Summer Season Year: 2017

JEL CODE: L85-L86 ID:350 K:129

ISSN Print: 2146-8508 Online 2147-1711

(ISO 18001-OH-0090-13001706 / ISO 14001-EM-0090-13001706 / ISO 9001-QM-0090-13001706 / ISO 10002-CM-0090-13001706) (TRADEMARK)

(2015/04315- 2015-GE-18972)

\begin{tabular}{|c|c|c|c|c|c|c|c|}
\hline \multirow{2}{*}{12} & \multirow{2}{*}{$\begin{array}{l}\text { Unpleasant news were published about me on the } \\
\text { internet. }\end{array}$} & $\mathrm{N}$ & 50 & 156 & \multirow{2}{*}{206} & \multirow{2}{*}{1.77} & \multirow{2}{*}{0.44} \\
\hline & & $\%$ & 24.3 & 75.7 & & & \\
\hline \multirow{2}{*}{13} & \multirow{2}{*}{ False rumors were spread about me on the internet. } & $\mathrm{N}$ & 30 & 176 & \multirow{2}{*}{206} & \multirow{2}{*}{1.86} & \multirow{2}{*}{0.36} \\
\hline & & $\%$ & 14.6 & 85.4 & & & \\
\hline \multirow{2}{*}{14} & \multirow{2}{*}{ Offensive messages were sent to me on the internet. } & $\mathrm{N}$ & 40 & 166 & \multirow{2}{*}{206} & \multirow{2}{*}{1.82} & \multirow{2}{*}{0.40} \\
\hline & & $\%$ & 19.4 & 80.6 & & & \\
\hline \multirow[t]{2}{*}{15} & \multirow[b]{2}{*}{ I was mocked on the internet. } & $\mathrm{N}$ & 19 & 187 & \multirow[b]{2}{*}{206} & \multirow[b]{2}{*}{1.91} & \multirow[b]{2}{*}{0.29} \\
\hline & & $\%$ & 9.2 & 90.8 & & & \\
\hline \multirow[b]{2}{*}{16} & \multirow{2}{*}{ I was given a bad name or nickname on the internet. } & $\mathrm{N}$ & 16 & 190 & \multirow{2}{*}{206} & \multirow{2}{*}{1.92} & \multirow{2}{*}{0.27} \\
\hline & & $\%$ & 7.8 & 92.2 & & & \\
\hline \multirow{2}{*}{17} & \multirow{2}{*}{$\begin{array}{l}\text { I was told things they couldn't tell to my face easily } \\
\text { on the internet or phone. }\end{array}$} & $\mathrm{N}$ & 56 & 150 & \multirow{2}{*}{206} & \multirow{2}{*}{1.73} & \multirow{2}{*}{0.45} \\
\hline & & $\%$ & 27.2 & 72.8 & & & \\
\hline \multirow[t]{2}{*}{18} & \multirow{2}{*}{$\begin{array}{l}\text { Threatening messages were sent to me from mobile } \\
\text { phone. }\end{array}$} & $\mathrm{N}$ & 23 & 183 & & & \\
\hline & & $\%$ & 11.2 & 88.8 & 206 & 1.89 & 0.32 \\
\hline 10 & My photos were sent to other people on the mobile & $\mathrm{N}$ & 17 & 189 & & 102 & 028 \\
\hline 19 & phone without permission. & $\%$ & 8.3 & 91.7 & 206 & 1.92 & 0.28 \\
\hline & Displeasing messages were sent to me on mobile & $\mathrm{N}$ & 31 & 175 & & & \\
\hline 20 & phone. & $\%$ & 15 & 85 & 206 & 1.85 & 0.36 \\
\hline 21 & Unreal rumors about me were spread on the mobile & $\mathrm{N}$ & 22 & 184 & 206 & 189 & 031 \\
\hline 21 & phone. & $\%$ & 10.7 & 89.3 & 200 & & 0.31 \\
\hline & Offensive messages were sent to me on the mobile & $\mathrm{N}$ & 29 & 177 & & & \\
\hline 22 & phone. & $\%$ & 14.1 & 85.9 & 206 & 1.86 & 0.35 \\
\hline & & $\mathrm{N}$ & 16 & 190 & & & \\
\hline 23 & I was mocked on the mobile phone. & $\%$ & 7.8 & 92.2 & 206 & 1.92 & 0.27 \\
\hline 24 & Iwas disturhed with the calls from moile phone & $\mathrm{N}$ & 51 & 155 & 206 & 176 & 043 \\
\hline 24 & I was aisturbed with the calls irom mobile pnone. & $\%$ & 24.8 & 75.2 & 200 & 1.10 & 0.75 \\
\hline
\end{tabular}

As specified in Table 4, it is observed that basketball referees have high sensitivity regarding cyber bullying at high level ( $\bar{x}=36.29)$.

While the highest score obtained from the scale is 42 , the lowest score is 22 . Such a scale value as 2.59 has been found to be close to yes. 


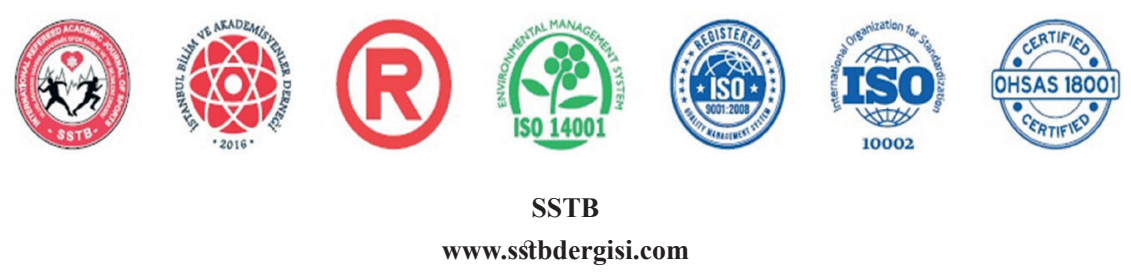

International Refereed Academic Journal of Sports, Health and Medical Sciences July - August - September Issue 24 Summer Season Year: 2017

JEL CODE: L85-L86 ID:350 K:129

ISSN Print: 2146-8508 Online 2147-1711

(ISO 18001-OH-0090-13001706 / ISO 14001-EM-0090-13001706 / ISO 9001-QM-0090-13001706 / ISO 10002-CM-0090-13001706) (TRADEMARK)

(2015/04315- 2015-GE-18972)

Table 6. Comparison of Cyber Sensibility and Cyber Victimization of Referees with Personal Variables

\begin{tabular}{|c|c|c|c|c|c|c|c|c|}
\hline \multicolumn{3}{|c|}{ Cyber Sensibility } & \multicolumn{3}{|c|}{ Personal Variables } & \multicolumn{3}{|c|}{ Cyber Victimization } \\
\hline $\mathbf{X}$ & SS & $\mathbf{p}$ & & $\mathbf{N}$ & $\%$ & $\mathbf{x}$ & SS & $\mathbf{p}$ \\
\hline & & & Sex & & & & & \\
\hline 2.60 & 0.28 & \multirow{2}{*}{$0.002 *$} & Male & 178 & 86.4 & 1.81 & 0.17 & \multirow{2}{*}{0.189} \\
\hline 2.52 & 0.36 & & Female & 28 & 13.6 & 1.83 & 0.18 & \\
\hline & & & Classification & & & & & \\
\hline 2.64 & 0.32 & 0.566 & A-classification & 30 & 14.6 & 1.81 & 0.19 & 0.296 \\
\hline 2.57 & 0.18 & $0.001 *$ & B-classification & 63 & 30.6 & 1.86 & 0.05 & $0.001 *$ \\
\hline \multirow[t]{2}{*}{2.58} & 0.33 & 0.566 & C-classification & 113 & 54.9 & 1.79 & 0.21 & 0.296 \\
\hline & & & \multicolumn{3}{|c|}{ Duration of Daily Internet Use } & & & \\
\hline 2.58 & 0.28 & \multirow{3}{*}{0.749} & $1-4$ hours & 158 & 76.7 & 1.82 & 0.17 & 0.352 \\
\hline 2.62 & 0.29 & & 5-8 hours & 42 & 20.3 & 1.81 & 0.14 & 0.352 \\
\hline 2.61 & 0.37 & & $9-12$ hours & 6 & 2.9 & 1.79 & 0.03 & $0.001 *$ \\
\hline 2.59 & 0.26 & 0.919 & Age & 206 & 100 & 1.82 & 0.11 & 0.963 \\
\hline 2.60 & 0.28 & 0.425 & Marital Status & 206 & 100 & 1.81 & 0.17 & 0.920 \\
\hline 2.62 & 0.25 & 0.726 & Education & 206 & 100 & 1.77 & 0.18 & 0.069 \\
\hline 2.59 & 0.29 & 0.535 & Profession & 206 & 100 & 1.80 & 0.18 & 0.841 \\
\hline 2.59 & 0.25 & 0.891 & $\begin{array}{l}\text { Starting Year for } \\
\text { Refereeing }\end{array}$ & 206 & 100 & 1.79 & 0.15 & 0.334 \\
\hline 2.55 & 0.28 & 0.259 & Priorities on the Internet & 206 & 100 & 1.80 & 0.18 & 0.298 \\
\hline 2.50 & 0.28 & 0.119 & $\begin{array}{l}\text { Place of Access for the } \\
\text { Internet }\end{array}$ & 206 & 100 & 1.82 & 0.15 & 0.052 \\
\hline 2.59 & 0.28 & 0.640 & Internet Tools & 206 & 100 & 1.80 & 0.18 & 0.360 \\
\hline
\end{tabular}

$* \mathrm{p}<0.05$

On the other hand, no significant difference was established between cyber sensibility and victimization and age, sex, marital status, education, profession, starting year of refereeing, classification, daily use of internet, pri- 


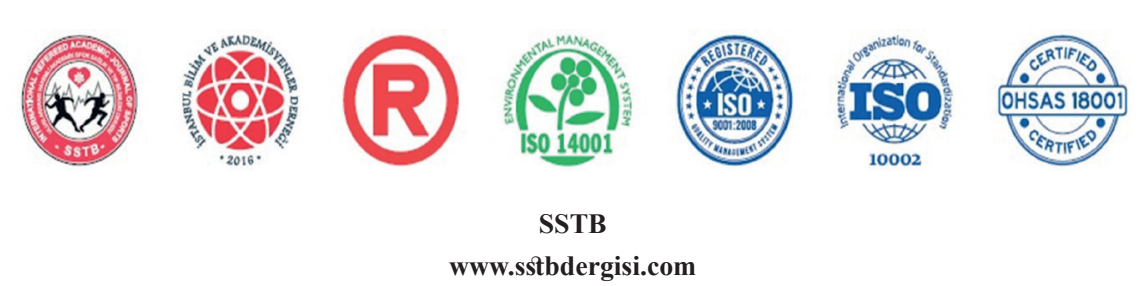

International Refereed Academic Journal of Sports, Health and Medical Sciences

July - August - September Issue 24 Summer Season Year: 2017

JEL CODE: L85-L86 ID:350 K:129

ISSN Print: 2146-8508 Online 2147-1711

(ISO 18001-OH-0090-13001706 / ISO 14001-EM-0090-13001706 / ISO 9001-QM-0090-13001706 / ISO 10002-CM-0090-13001706) (TRADEMARK)

(2015/04315- 2015-GE-18972)

orities on internet, place of access for internet and internet tools ( $p>0.05$ ).

\section{DISCUSSION}

Analyzing the prominent data of the participant basketball referees, it is observed that $86.4 \%$ of them are male, $42.23 \%$ is aged between 20 $25,65.50 \%$ is single, $71.4 \%$ has a bachelor's degree, $43.2 \%$ is self-employed, $54.9 \%$ is Cclassification referees, $30.6 \%$ of them mostly visit the website "Facebook", $55.8 \%$ connects internet from home and $55.9 \%$ prefers mobile phones and tablets to connect internet.

The findings obtained following the research are surprising. Although the participant basketball referees have high sensibility related to cyber bullying $(\bar{x}=36.29)$, it has been determined that they are subject to high cyber victimization ( $\bar{x}=43.55)$. In other words, basketball referees are subject to cyber victimization although they show sensibility. This situation can be explained with the possibilities beyond the control of the referees.

The sensibility of male basketball referees has been found to be significantly higher than the female basketball referees. This can be explained with the low number of female basketball referees participating in the research. The researchers analyzing the gender factor in cyber bullying have obtained various results. Many researchers have stated that gender doesn't play a deterministic role in cyber bullying, males and females are in the roles of victim and bully at similar frequency (Patchin and Hinduja, 2006: 165; Slonje and Smith, 2008: 151; Smith et al., 2008: 378; Williams and Guerra, 2007: 18; Topçu vd., 2008: 646). In research results emphasizing the importance of gender difference, females are observed to be more victimized than males (Mesch, 2009: 389; Arıcak vd., 2008: 110; Kowalski and Limber, 2007: 28; Li, 2007: 1788).

Examining the basketball referees by their classifications, it has been determined that there is a significant difference between groups regarding sensibility for cyber bullying and cyber victimization and this difference results from the B-classification referees. The fact that B-classification referees display less cyber sensibility than other referees and they are subject to cyber victimization more has been found to be significant. In this regard, it can be stated that the B-classification referees are not aware of the cyber bullying actions they may encounter in virtual environments and are not inclined to take measures to ensure their personal security against such actions. Following the analysis of 80 studies in international literature with meta-analysis method, the ratios of cyber bullying and cyber victimization have been established as $15-16 \%$ approximately. According to the researches conducted in Turkey, it has been reported that the ratio of cyber bullying varies between $6.4 \%$ and $47.6 \%$ 


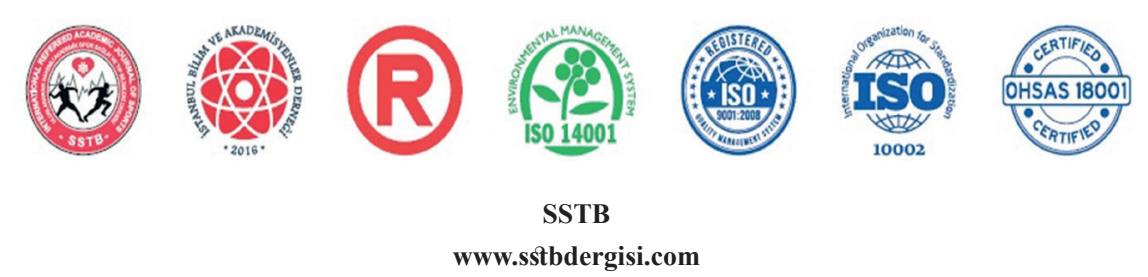

International Refereed Academic Journal of Sports, Health and Medical Sciences

July - August - September Issue 24 Summer Season Year: 2017

JEL CODE: L85-L86 ID:350 K:129

ISSN Print: 2146-8508 Online 2147-1711

(ISO 18001-OH-0090-13001706 / ISO 14001-EM-0090-13001706 / ISO 9001-QM-0090-13001706 / ISO 10002-CM-0090-13001706) (TRADEMARK)

(2015/04315- 2015-GE-18972)

dex.php?option=com_gts\&view $=$ gts 25.12.2014

TİRYAKI, Ş., (2000). Spor Psikolojisi, Eylül Yayınları, Ankara, s.149

TOPÇU, Ç., ERDUR-BAKER, Ö., ÇAPAAYDIN, Y., (2008). Examination of Cyberbullying experiences among Turkish students from different school types. Cyberpsychology and Behavior, 11(6) ss.643-648

UZER, Ç.T., TANRIKULU, I.., (2017). Siber Zorbalığı Önleme ve Müdahale Programları: Ulusal Bir Alanyazın Taramas1, Uludağ Üniversitesi Eğitim Fakültesi Dergisi, 30 (1), ss.1-17

WILLARD, N.E., (2005). Educator's guide to cyberbullying and cyberthreats: Responding to the challenge of online social aggression, threats, and distress. Retrived September 23, 2016, from http:// www. csriu.org /cyberbully Docs / cbct educator.pdf

WILLIAMS, K.R., GUERRA, N.G., (2007). Prevalence and predictors of internet bullying. Journal of Adolescent Health, ss.41-14-21

WOLAK, J., MITCHELL, K.J., FINKELHOR, D., (2007). Does online harassment constitute bullying? An exploration of online harassment by known peers and online only contacts. Journal of Adolescent Health, ss.41-51-58
YBARRA, M.L., DIENER, WEST, M., LEAF, P.J., (2007). Examining the overlap in internet harassment and school bullying: Implications for school intervention. Journal of Adolescent Health, ss.41-42-50

YBARRA, M.L., MITCHELL, K.J., (2004a). Online aggressor/targets, aggressors and targets: a comparison of associated youth characteristics. J Child Psychol Psychiatry, 45: ss.1308-1316

YBARRA, M.L., MITCHELL, K.J., (2004b). Youth engaging in online harassment: Association with caregiver-child relationships, internet use and personal characteristics. Journal of Adolescence, 27, ss.319-336

YILMAZ, I..H., (2015). Futbol Hakemlerinin Sanal Duyarlılık ve Mağduriyetlerinin İncelenmesi, Yüksek Lisans Tezi, Elazığ: Fırat Üniversitesi, Sağlık Bilimleri Enstitüsü Beden Eğitimi ve Spor Anabilim Dalı

AUTHOR NOTES. This study was submitted as a verbal presentation in the 10th International Conference on Physical Education, Sports and Physical Therapy Firat University, Elazig, Turkev, 1820 November, 2016. 